\title{
JESYA
}

JURNAL EKONOMI \& EKONOMI SYARIAH

Jurnal Ekonomi \& Ekonomi Syariah Vol 5 No 1, Januari 2022

E-ISSN : 2599-3410 | P-ISSN : 2614-3259

DOI : https://doi.org/10.36778/jesya.v5i1.640

\section{ATRIBUT PRODUK DALAM MENINGKATKAN LOYALITAS PELANGGAN (studi pada Gorontalo Post)}

\author{
Herlinda Mansur \\ Universitas Gorontalo \\ herlinmansur@gmail.com \\ Deby Rita Karundeng \\ Universitas Gorontalo \\ Mohamad Afan Suyanto \\ Universitas Gorontalo
}

\begin{abstract}
This study uses a quantitative approach emphasizing the analysis on numerical data that is processed by statistical methods. This study aims to determine and analyze the effect of product attributes, including product quality, design, brand, price and service, simultaneously and partially influence customer loyalty in Gorontalo Post newspaper and analyze the dominant variables affecting customer loyalty. The research results obtained are Simultaneously product attributes consisting of product quality, product style and design, product prices, product brands, product services have a positive and significant influence on customer loyalty Gorontalo Post. Partially, each of the independent variables studied, namely product quality, product style and design, product price, product brand, product service has an influence on Gorontalo Post customer loyalty. The dominant indicator in the formation of product quality is the indicator of completeness of news. The dominant indicator in shaping the style and design of Gorontalo Post products is the polite language style indicator. Indicators that have a dominant contribution in product prices are indicators of price conformity with quality. The dominant indicator in shaping the product brand in Gorontalo Post is the easily recognizable brand indicator. The dominant indicator in shaping the Gorontalo Post product service is the Gorontalo Post delivery indicator that is always on time. The product quality variable applied by Gorontalo Post has the most dominant effect on customer loyalty

Keywords Product Attributes, Customer Loyalty
\end{abstract}

\section{PENDAHULUAN}

Loyalitas pelanggan sangat penting artinya bagi perusahaan yang ingin menjaga kelangsungan hidup usahanya maupun keberhasilan usahanya. Loyalitas pelanggan merupakan tiket menuju sukses dalam semua bisnis. Dengan adanya loyalitas yang tercipta pada pelanggannya, maka perusahaan akan memperoleh dua keutungan sekaligus yaitu mendapatkan profitabilitas dengan terjualnya produk yang mereka hasilkan dan menarik pelanggan baru karena meilhat loyalitas dari pelanggan yang telah ada, ini berarti perusahaan semakin banyak memperoleh laba untuk kelangsungan usahanya.

Keandalan sebagai perilaku yang diantisipasi untuk item atau manfaat yang mencakup masuk akal mendorong pembelian atau perubahan pemahaman manfaat, atau kebiasaan buruk sebaliknya seberapa 
besar kemungkinan klien akan beralih ke merek lain atau pemasok manfaat lainnya. Pengabdian dapat berupa pekerjaan pemenuhan klien, hambatan, batasan pengalihan, dan keluhan pelanggan. Klien yang terpenuhi akan dapat membuat pembelian ulang di masa depan dan memberi tahu orang lain bagaimana perasaan mereka. Jadi dapat dikatakan ketergantungan adalah tingkat keterpaduan hubungan dari pembeli yang terpenuhi dengan barang yang telah gunakan.

Atribut produk adalah unsur-unsur produk yang dipandang penting oleh konsumen dan dijadikan dasar pengambilan keputusan pembelian dan unsur-unsur itu meliputi merek, kemasan, pemberian label (labeling), jaminan (garansi), harga, dan pelayanan produk.

Pengembangan produk jasa memerlukan pendefenisian manfaat-manfaat yang akan ditawarkan. Manfaatmanfaat tersebut kemudian dikomunikasikan dan disampaikan melalui atribut-atribut produk seperti kualitas produk, fitur produk, serta gaya dan desain.

Surat kabar sebagai suatu produk yang dibeli konsumen atas preferensi tertentu. Sebagian konsumen karena isinya beragam seperti memberitakan masalah ekonomi, politik, pendidikan, gaya hidup, hukum dan kriminal, olahraga dan sebagainya. Beberapa konsumen juga mengiginkan isi yang lebih spesifik seperti berita lokal, regional, nasional maupun internasional. Sebagian juga konsumen tertarik pada surat kabar karena tampilannya, warna tulisan dan gambar/foto, lay out serta desainnya. Semua kebutuhan konsumen tersebut tentunya tidak semua dapat dipenuhi oleh produsen atau pengusaha surat kabar. Olehnya itu, pihak manajemen surat kabar harus memilih segmen pasar mana yang akan dimasuki dan pasar mana yang memberikan keuntungan bagi perusahaan dalam jangka panjang. Dalam mentukan target pasar maka diperlukan analisis pasar yang mendalam.

Penerbit atau pihak manajemen surat kabar memiliki kepentingan untuk memperhatikan berbagai atribut produk karena atribut produk merupakan unsur-unsur produk yang dipandang penting oleh konsumen dan dijadikan dasar pengambilan keputusan pembelian agar suatu produk yang dibutuhkan dan diinginkan dibeli oleh konsumen, maka produk tersebut harus memiliki keunggulan dibandingkan dengan produk pesaing lainnya. Selain itu perusahaan harus memasarkan produknya lebih baik dibandingkan dengan pesaing.

Pada garis besarnya perusahaan harus mengerti apa yang menjadi kebutuhan dan keinginan konsumen terhadap produk yang dihasilkan diantara tentang harga yang terjangkau, kualitas yang baik, pelayanan yang memuaskan serta rasa yang dapat memenuhi selera konsumen.

Perilaku konsumen pada hakekatnya untuk memahami "why do consumer do what they do". Perilaku konsumen adalah semua kegiatan , tindakan, serta proses psikologis yang mendorong tindakan tersebut pada saat sebelum membeli, ketika membeli, mengguanakan, menghabiskan barang atau jasa setelah melakukan kegiatan evaluasi.

Istilah perilaku konsumen diartikan sebagai perilaku yang diperlihatkan konsumen dalam mencari, membeli, menggunakan, mengevaluasi, dan menghabiskan barang dan jasa yang mereka harapkan akan memuaskan kebutuhan mereka.

Banyak perusahaan termasuk Gorontalo Post sudah mengklaim, bahwa mereka telah memuaskan para pelanggannya. Kepuasan menurut Kotler dalam (Suyanto, Usu, \& Moodoeto, 2019) menjelaskan bahwa Kepuasan pelanggan adalah tingkat perasaan seseorang setelah membandingkan kinerja atau hasil yang dirasakannya dibandingkan dengan harapannya. Namun diantara mereka, masih cukup banyak pula yang belum yakin, bahwa para pelanggannya telah menjadi pelanggan loyal. Padahal, Loyalitas merupakan kunci utama bagi perusahaan menjamin profitibilitas jangka panjang. Mereka semua menyadari bahwa untuk mencapai loyalitas pelanggan dibutuhkan perjalanan panjang. Perusahaan memang perlu membuktikan kepada pelanggannya dengan memberikan produk yang berkualitas secara konsisten di setiap interaksi dalam kurung waktu yang panjang. Untuk itu, setiap perusahaan perlu melakukan perbaikan atribut produk secara terintegrasi yang baik dari sudut pelanggan. 
Dengan mengetahui pentingnya atribut-atribut mana yang diharapkan oleh konsumen serta dengan mengetahui sejauh mana produk yang ditawarkan perusahaan sesuai dengan apa yang diharapkan pelanggan, maka perusahaan diharapkan dapat mengetahui dengan cara apa ia dapat memuaskan kebutuhan dan keinginan konsumennya bahkan sekaligus meningkatkan loyalitas pelanggan. Loyalitas pelanggan yang dikemukakan oleh peneliti disini adalah loyalitas pelanggan dari pembaca surat kabar Gorontalo Post di Provinsi Gorontalo.

\section{TINJAUAN PUSTAKA}

\section{Konsep Atribut Produk}

Atribut produk mempunyai pengaruh besar terhadap pada persepsi pembeli terhadap produk. Hal ini disebabkan karena secara fisik atribut produk membawa berbagai macam manfaat yang dibutuhkan dan diinginkan pembeli. Oleh karena itu setiap perusahaan, harus berhati dalam mengambil keputusan yang bersangkutan hal tersebut.

Pengembangan produk dan jasa memerlukan pendefenisian manfaat-manfaat yang akan ditawarkan. Manfaat-manfaat tersebut kemudian dikomunikasikan dan disampaikan melalui atribut produk.

Menurut Tjiptono (2013 : 103) atribut produk adalah unsur-unsur produk yang dipandang penting oleh konsumen dan dijadikan dasar pengambilan keputusan pembelian.

Sedangkan Simarora (2011; 147) mendefinisikan atribut produk sebai faktor-faktor yang dipertimbangkan saat membeli produk, seperti harga, kualitas, kelengkapan fungsi (fitur), desain, layanan purna jual, dan sebagainya. Suatu atribut produk merupakan suatu kesatuan dari bermacam-macam atribut yang membentuknya, dimana masing-masing atribut mempunyai kapasitas yang berbeda-beda dalam memberikan keputusan kepada pemakai produk tersebut. Keputusan dalam membeli suatu produk merupakan faktor internal yang sulit dilihat dan diukur, sehingga konsumen atau pemakai produk akan memandang suatu produk dari sudut pandang yang berbeda-beda.

\section{Unsur-Unsur Atribut Produk}

Setiap produk mempunyai atribut yang berbeda-beda, sehingga konsumen dihadapkan pada berbagai atribut yang ditawarkan oleh perusahaan. Perusahaan mempunyai tugas untuk memperhatikan dan mengevaluasi atribut produk yang ditawarkan, apakah atribut dari produk tersebut sudah memenuhni kebutuhan dan keinginan konsumen atau belum.

Menurut Kotler dan Amstrong (2013 : 347) pengembangan produk jasa memerlukan pendefenisian manfaat-manfaat yang akan ditawarkan. Manfaat-manfaat tersebut kemudian dikomunikasikan dan disampaikan melalui atribut-atribut produk seperti kualitas produk, fitur produk, serta gaya dan desain produk.

1. Kualitas produk

Kualitas produk menunjukkan kemampuan suatu produk untuk melakukan fungsi-fungsinya. Kemampuan itu meliputi daya tahan, kehandalan, ketelitian uang dihasilkan, kemudahan dioperasikan dan diperbaiki, dan atribut lain yang berharga pada produk secara keseluruhan. Agar dapat bersaing di pasar secara berhasil produk harus memiliki mutu yang unggul dibandingkan dengan produk-produk pesaing yang setingkat. Hanya perusahaan yang mempunyai kualitas yang terbaik yang akan berhasil dalam memenangkan persaingan. Sebagian besar perusahaan menyadari akan pentingnya kulitas, maka mereka mengimplemantasikan program Manajemen kulitas total (TQM), yaitu usaha-usaha untuk meningkatkan kualitas produk dan proses secara konsisten di setiap tahap dalam kegiatan operasinya. Tujuan akhir dari kualitas total adalah meningkatkan kepuasan dan nilai bagi pelanggan. Saat ini secara nyata kualitas telah menjadi keharusan agar dapat bersaing, hanya perusahaan yang mempunyai kualitas yang terbaik yang akan berhasil. 
2. Gaya dan Desain Produk

Cara lain untuk menambahkan nilai pelanggan adalah melalui gaya dan desain produk yang khas. Konsep desain lebih luas dibandingkan gaya. Gaya mengedepankan tampilan luar dan semata-mata menjelaskan penampilan produk tertentu. Sedangkan desain bukan sekedar tampilan luar semata, desain masuk ke jantung produk, desain yang baik dapat memberikan kontribusi dalam hal keg\$unaan produk dan juga penampilannya. Desain dapat menjadi alat persaingan yang sangat baik bagi armada pemasaran perusahaan.

Menurut Tjiptono (2013 : 103) dan Simamora (2011 :195), unsur-unsur yang penting dalam atribut produk diantaranya meliputi merek, kemasan, pemberian label (labeling), jaminan (garansi), harga, dan pelayanan. Berikut ini adalah uraian tentang unsur-unsur atribut produk mengikuti pendapat diatas yaitu :

1. Merek

Merek merupakan nama, istilah, tanda, simbol/lambang, warna, gerak atau kombinasi atribut-atribut produk lainnya yang diharapkan dapat memberikan identitas dan diferensiasi terhadap produk pesaing.

2. Kemasan

Pengemasan (packaging) merupakan proses yang berkaitan dengan perancangan dan pembuatan wadah atau pembungkus untuk suatu produk. Kemasan yang inovatif dapat memberikan perusahaan keunggulan terhadap pesaingnya.

3. Pemberian Label (Labeling)

Label merupakan informasi tertulis tentang produk yang dicetak pada badan kemasan. Label menampilkan beberapa fungsi. Pada tingkatan paling akhir, label mengidentifikasi produk dan merek, menjelaskan beberapa hal mengenai produk, siapa yang membuatnya, dimana dibuat, isinya, bagaimana produk tersebut digunakan, dan bagaimana menggunakannya dengan aman.

4. Jaminan (Garansi)

Jaminan merupakan janji berupa kewajiban produsen atas produknya kepada konsumen, dimana para konsumen akan diberi ganti rugi bila produk ternyata tidak bisa berfungsi sebagaimana yang diharapkan atau dijanjikan. Jaminan bisa meliputi kualitas produk, reparasi, ganti rugi, dan sebagainya

5. Pelayanan

Pelayanan merupakan setiap kegiatan atau mannfaat yang ditawarkan suatu pihak kepada pihak lain, yang pada dasarnya tidak berwujud dan tidak mengakibatkan kepelikan apa pun. agar pelayanan yang diberikan berkualitas menurut (Suyanto \& Setiawan, 2019) yaitu perusahaan harus mampu dalam memberikan dan memuaskan kebutuhan konsumen.

6. Harga

Harga menurut (M, Karundeng, \& Suyanto, 2021) adalah kumpulan beberapa beban berupa uang yang terasosiasi pada suatu produk berupa barang atau jasa.

\section{Loyalitas Pelanggan}

Loyalitas menurut Aaker dalam Mouren Margaretha (2014: 297) dinyatakan sebagai suatu perilaku yang diharapkan atas suatu produk atau layanan yang antara lain meliputi kemungkinan pembelian lebih lanjut atau perubahan perjanjian layanan, atau sebaliknya seberepa besar kemungkinan pelanggan akan beralih kepada merek lain atau penyedia layanan lain.

Setiap perusahaan pasti menginginkan kensumennya loyal, karena konsumen yang loyal akan memberikan keuntungan jangka panjang bagi perusahaan. Selain itu, konsumen yang loyal merupakan tujuan akhir dari setiap perusahaan.

Pengertian loyalitas yang didefinisikan oleh Tjiptono (2000), Loyalitas adalah situasi dimana konsumen bersikap positif terhadap produk atau produsen (Penyedia jasa) dan disertai pola pembelian ulang yang konsisten, 
Sedangkan menurut Lovelock, Service Marketing (2014 :435) Loyalitas menggambarkan keinginan konsumen untuk terus berlangganan dalam jangka waktu yang panjang, melakukan pembelian dan menggunakan barang dan jasa secara berulang, dan merekomendasikan produk perusahaan kepada teman dan kolegannya.

Dari definisi diatas dapat disimpulkan bahwa loyalias merupakan suatu sikap positf konsumen terhadap suatu produk atau jasa yang disertai dengan perilaku pembelian secara berulang dan bersifat konsisten, yang selanjutnya mereka atau konsumen merekomendasikan barang atau jasa perusahaan tersebut kepada orang lain.

1. Karakteristik Loyalitas pelanggan

Konsumen yang loyal merupakan aset tak ternilai bagi perusahaan. Bagaimana menilai konsumen itu loyal atau tidak, Tjiptono (2000) mengemukakan bebarapa karakteristik dari pelanggan yang loyal, antara lain adalah :

a. Melakukan pembelian ulang yang konsisten

b. Merekomendasikan produk perusahaan kepada orang lain

c. Konsumen tidak mudah beralih pada produk pesaing.

2. Tipe-tipe loyalitas Pelanggan

Dalam cakupan yang lebih luas, loyalitas pelanggan (custumer loyalty) dapat didefinisikan sebagai komitmen pelanggan terhadap suatu merek, toko, atau pemasok, berdasarkan sikap yang sangat positif dan tercermin dalam pembelian ulang yang konsisten. Definisi tersebut mencakup dua komponen penting, yaitu loyalitas sebagai perilaku dan loyalitas sebagai sikap. Kombinasi kedua komponen itu menghasilkan empat situasi kemungkinan loyalitas atau disebut juga dengan tipe loyalitas pelanggan. Tipe-tipe pelanggan yang dimaksud adalah :

a. No Loyalty

Bila sikap dan perilaku pembelian ulang pelanggan sama-sama lemah, maka loyalitas tidak terbentuk. Hal ini disebabkan bila suatu produk/jasa baru diperkenalkan tidak mampu mengkomunikasikan keunggulan unik produknya dan penyebab lainnya adalah berkaitan dengan dinamika pasar, dimana merek-merek yang berkompetisi dipersepsikan serupa atau sama.

b. Spurious Loyalty

Bila sikap yang relatif lemah diserta pola pembelian ulang yang kuat, situasi semacam ini ditandai dengan pengaruh faktor non sikap terhadap perilaku, misalnya faktor situasional.

c. Latent Loyalty

Situasi ini tercermin bila sikap yang kuat disertai pola pembelian ulang yang lemah. Situasi ini disebabkan pengaruh faktor-faktor non sikap yang sama kuat atau bahkan cendrung lebih kuat daripada faktor sikap dalam menentukan pembelian ulang.

d. Loyalty

Situasi ini merupakan situasi ideal yang paling diharapkan para pemasar, dimana konsumen bersikap positif terhadap produk atau produsen (penyedia jasa) dan disertai pola pembelian ulang yang konsisten.

\section{METODOLOGI PENELITIAN}

\section{Populasi Dan Sampel}

\section{Populasi}

Dalam penelitian ini yang dijadikan populasi adalah pelanggan surat kabar Gorontalo Post yang berdomosili di Provinsi Gorontalo 


\section{Sampel}

Mengingat jumlah populasi dalam penelitian tidak terukur (tak terhingga), maka jumlah sampel didasarkan pada jumlah indikator variabel yang diteliti yaitu paling sedikit 5 kali jumlah indikator variabel (Ferdinand, 2014). Adapun jumlah indicator variabel dalam penelitian ini adalah 24 indikator sehingga jumlah sampel minimal yang representative adalah 120 sampel.

\section{Uji Validitas dan Reabiltas}

1. Uji Validitas

Uji validitas dilakukan dengan membandingkan nilai $r$ hitung dengan nilai $r$ tabel. Pernyataan dikatakan valid apabila nilai $r$ hitung lebih besar dari pada nilai $r$ tabel dengan menggunakan level signifikan 5\%. Untuk menguji validitasnya menggunakan korelasi Product Moment Pearson (Suharsimi, 2006:170)

2. Uji Reabilitas

Untuk menghitung reliabilitas instrumen maka dilakukan analisis dengan menggunakan tehnik belah dua. Dengan memakai tehnik belah dua, dalam penelitian ini reliabilitas kemudian diukur dengan tehnik Spearman-Brown.

\section{Uji Asumsi Klasik}

1. Uji Normalitas

Pengujian data normalitas menurut Ghozali (2005:110) bertujuan untuk menguji apakah dalam model regresi variabel penggangu atau residual memiliki distribusi normal. Ada dua cara untuk mendeteksi apakah residual berdistribusi normal atau tidak yaitu dengan analisis gambar berupa plot dan uji statistik dengan melihat nilai kurtosis dan skewness.

\section{Uji Multikolinearitas}

Uji multikolinearitas menurut Ghozali (2005:91) bertujuan untuk menguji apakah dalam model regresi ditemukan adanya korelasi antar variabel independent. Model regresi yang baik seharusnya tidak terjadi korelasi antar variabel independent. Ketentuan uji multikolinearitas sebagai berikut :

a. Jika $\mathrm{R}^{2}$ tinggi tapi variabel independent banyak yang tidak signifikan, maka dalam model regresi terdapat multikolinearitas.

a. Menganalisis matriks korelasi variabel independent. Jika korelasi antar variabel independent tinggi yaitu diatas 0,90 maka terdapat multikolinearitas.

a. Melihat nilai tolerance lebih kecil dari $10 \%$ dan nilai VIF lebih besar dari $10 \%$ berarti ada multikolinearitas

Bila ternyata dalam model regresi terdapat multikolinearitas, maka harus menghilangkan variabel independent yang mempunyai korelasi tinggi.

3. Uji heteroskedastisitas

Salah satu cara untuk mendeteksinya adalah dengan melihat gambar plot antara nilai prediksi variabel terikat (ZPRED) sebagai X dengan residualnya (SRESID) sebagai Y.

Jika ada pola tertentu, seperti titik-titik yang ada membentuk pola tertentu yang teratur (bergelombang, melebar kemudian menyempit), maka mengindikasikan telah terjadi heteroskedastisitas. Jika tidak ada pola yang jelas, serta titik-titik menyebar pada sumbu Y, maka tidak terjadi heteroskedastisitas.

\section{Analisis data}

\section{Analisis Deskriptif}


Analisis ini merupakan analisis yang bersifat memberi keterangan atau penjelasan tentang subjek yang dibahas tanpa menggunakan perhitungan angka. Untuk menganalisis data kualitatif dapat dari pengumpulan hasil penelitian dengan menggunakan cara persentase.

\section{Analisis Regresi}

Untuk mengetahui pengaruh perubahan variabel independen terhadap dependen baik secara sendirisendiri maupun secara bersama-sama, maka digunakan Regresi Berganda (Multiple regression). Dengan rumus :

$$
Y=B_{0}+\beta_{1} X_{1}+\beta_{2} X_{2}+\beta_{3} X_{3}+\beta_{4} X_{4}+\beta_{5} X_{5}+e_{i}
$$

\section{HASIL PENELITIAN DAN PEMBAHASAN}

\section{Analisis Hasil Penelitian}

\section{Uji Validitas Dan Reliabilitas Instrumen}

Untuk menguji konstruk pertanyaan-pertanyaan dalam kuesioner, peneliti melakukan pre-test kepada 30 responden yang sesuai dengan syarat sampel penelitian. pre-test untuk memeriksa validitas dan reliabilitas kuesioner penelitian. Pengujian validitas dan reliabilitas menggunakan SPSS 17.

Uji reliabilitas akan menunjukkan bahwa indikator-indikator memiliki konsistensi yang baik dalam mengukur variabel latennya. Syaratnya yaitu cronbach's alpha $(\alpha)$ sebesar 0,6 . Sedangkan, uji validitas adalah pengujian analisis faktor berdasarkan variabel-variabel yang ada di dalam penelitian ini. Persyaratan untuk uji validitas yaitu sebesar $\geq 0,5$.

\section{Tabel 1}

Hasil Uji Validitas dan Reliabilitas

\begin{tabular}{|l|l|l|l|}
\hline Variabel Laten & Indikator & $\begin{array}{l}\text { corrected } \\
\text { item-total } \\
\text { correlation }\end{array}$ & $\begin{array}{l}\text { Croncbac's } \\
\text { Alpha }\end{array}$ \\
\hline \multirow{5}{*}{ Kualitas produk } & $\mathrm{X} 1.1$ & 0,596 & 0,784 \\
\cline { 2 - 4 } & $\mathrm{X} 1.2$ & 0,533 & 0,812 \\
\cline { 2 - 4 } & $\mathrm{X} 1.3$ & 0,686 & 0,743 \\
\cline { 2 - 4 } & $\mathrm{X} 1.4$ & 0,728 & 0,719 \\
\hline \multirow{4}{*}{$\begin{array}{c}\text { Gaya dan desain } \\
\text { produk }\end{array}$} & $\mathrm{X} 2.1$ & 0,720 & 0,810 \\
\cline { 2 - 4 } & $\mathrm{X} 2.2$ & 0,712 & 0,810 \\
\cline { 2 - 4 } & $\mathrm{X} 2.3$ & 0,763 & 0,787 \\
\cline { 2 - 4 } & $\mathrm{X} 2.4$ & 0,610 & 0,850 \\
\hline \multirow{5}{*}{ Harga Produk } & $\mathrm{X} 3.1$ & 0,607 & 0,735 \\
\cline { 2 - 4 } & $\mathrm{X} 3.2$ & 0,527 & 0,794 \\
\cline { 2 - 4 } & $\mathrm{X} 3.3$ & 0,608 & 0,747 \\
\cline { 2 - 4 } & $\mathrm{X} 3.4$ & 0,626 & 0,721 \\
\hline Merek produk & $\mathrm{X} 4.1$ & 0,570 & 0,722 \\
\cline { 2 - 4 } & $\mathrm{X} 4.2$ & 0,641 & 0,781 \\
\cline { 2 - 4 } & $\mathrm{X} 4.3$ & 0,569 & 0,779 \\
\cline { 2 - 4 } & $\mathrm{X} 4.4$ & 0,637 & 0,783 \\
\hline
\end{tabular}




\begin{tabular}{|l|l|l|l|}
\hline Pelayanan produk & X5.1 & 0,663 & 0,835 \\
\cline { 2 - 4 } & X5.2 & 0,597 & 0,869 \\
\cline { 2 - 4 } & X5.3 & 0,837 & 0,755 \\
\cline { 2 - 4 } & X5.4 & 0,739 & 0,802 \\
\hline \multirow{5}{*}{ Loyalitas } & Y1 & 0,532 & 0,798 \\
\cline { 2 - 4 } & Y2 & 0,530 & 0,799 \\
\cline { 2 - 4 } & Y3 & 0,687 & 0,725 \\
\cline { 2 - 4 } & Y4 & 0,756 & 0,788 \\
\hline
\end{tabular}

Sumber : data diolah, 2021

Berdasarkan informasi dari Tabel 1 telah menunjukkan bahwa seluruh variabel laten memiliki validitas dan reliabilitas yang baik yaitu nilai corrected item-total correlation $\geq 0,5$ dan cronbach's alpha $(\alpha)$ sebesar 0,6. Sehingga, pelaksanaan survei dilanjutkan dengan menyebarkan kuesioner yang sesungguhnya dan kemudian dilakukan pengujian model analisis regresi linier berganda.

\section{Uji Asumsi Klasik}

a) Uji Normalitas

Uji Normalitas adalah salah satu bagian dalam uji asumsi klasik untuk menilai kelayakan suatu data yang tersebar dalam kelompok data dinilai memiliki distribusi yang sesuai atau normal atau tidak. Pengujian ini bermaksud untuk penentuan data yang sudah dikumpulkan dengan cara populasi normal.

Uji normalitas bisa menggunakan grafik data ploting, dimana menurut Gozali (2011), model regresi dikatakan berdistribusi normal jika data titil-titik yang tergambarkan secara nyata berdasarikutan garis yang ada secara diagonal. Untuk itu, uji normalitas data dalam penelitian ini seperti nampak di bawah ini

Gambar 1. Uji Normalitas

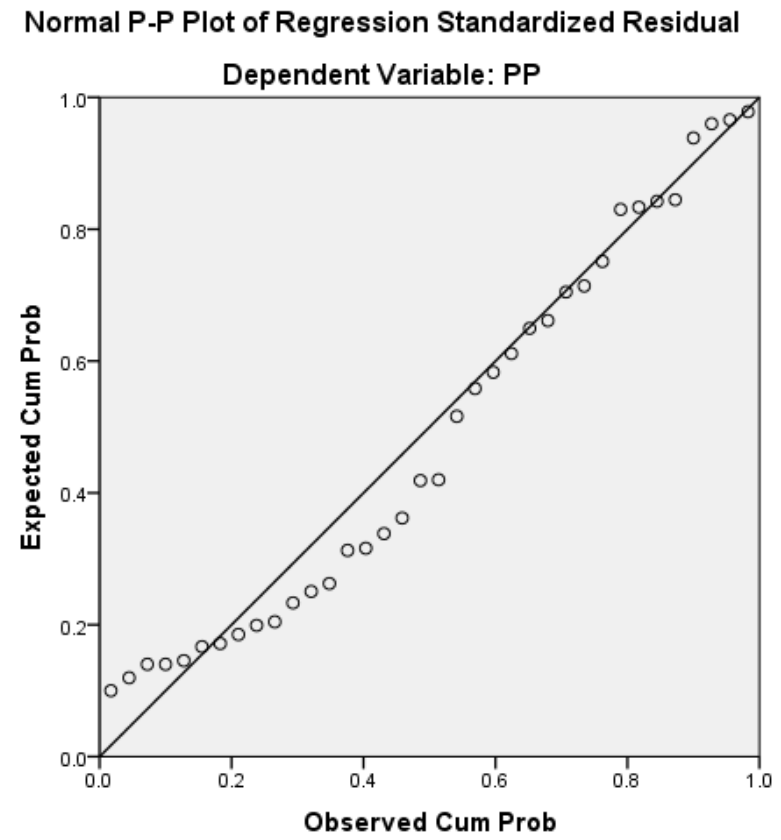

Sumber: Print Out SPSS, Data diolah, 2021 
Gambar 1 memperlihatkan bahwa data penelitian menghasilkan sebaran titik yang mengikuti diagonal garis dan dapat ditarik kesimpulan bahwa penelitian ini menggunakan data yang berdistribusi secara normal.

b) Uji Multikolinearitas

Multikolinearitas adalah sebuah situasi yang menunjukkan adanya korelasi atau hubungan kuat antara dua variabel bebas atau lebih dalam sebuah model regresi berganda. Model regresi yang dimaksud dalam hal ini antara lain: regresi linear, regresi logistik, regresi data panel dan cox regression. Dalam situasi terjadi multikolinearitas dalam sebuah model regresi berganda, maka nilai koefisien beta dari sebuah variabel bebas atau variabel predictor dapat berubah secara dramatis apabila ada penambahan atau pengurangan variabel bebas di dalam model.

Oleh karena itu, multikolinearitas tidak mengurangi kekuatan prediksi secara simultan, namun mempengaruhi nilai prediksi dari sebuah variabel bebas. Nilai prediksi sebuah variabel bebas disini adalah koefisien beta. Oleh karena itu, sering kali kita bisa mendeteksi adanya multikolinearitas dengan adanya nilai standar error yang besar dari sebuah variabel bebas dalam model regresi. Berdasarkan penjelasan di atas, maka dapat disimpulkan bahwa, jika terjadi multikolinearitas, maka sebuah variabel yang berkorelasi kuat dengan variabel lainnya di dalam model, kekuatan prediksinya tidak handal dan tidak stabil. Dan pengertian multikolinearitas adalah sesungguhnya terletak pada ada atau tidak adanya korelasi antar variabel bebas.

Uji multikolinearitas yang digunakan dalam penelitian ini adalah dengan melihat Tolerance dan nilai VIF (Variance Inflation Factor). Jika nilai Tolerance lebih besar dari 0,10; maka tidak terjadi multikolinearitas, sebaliknya jika nilai Tolerance lebih kecil atau sama dengan 0,10; maka terjadi multikolinearitas. Apabila dilihat dari nilai VIF, maka korelasi antar variabel bisa dikatakan bebas multikolinearitas jika nilai VIF lebih kecil dari 10. Jika VIF lebih besar atau sama dengan 10, maka terjadi multikolinearitas. Uji multikolinearitas mendapatkan hasil sebagai berikut.

Tabel 2

Uji Multikolinearitas

Coefficients $^{\mathbf{a}}$

\begin{tabular}{|ll|l|l|}
\hline \multirow{2}{*}{ Model } & \multicolumn{2}{|l|}{ Collinearity Statistics } \\
\cline { 3 - 4 } & Tolerance & VIF \\
\hline 1 & Kualitas Produk & .204 & 4.908 \\
& Gaya \& Desain Produk & .395 & 2.532 \\
& Harga Produk & .281 & 3.556 \\
& Merek Produk & .315 & 3.173 \\
& Pelayanan Produk & .211 & 4.748 \\
\hline
\end{tabular}

a. Dependent Variable: Loyalitas

Sumber: Print Out SPSS, Data diolah, 2021

Berdasarkan tabel diatas, terlihat bahwa semua nilai tolerance lebih besar dari 0,1 dan nilai Variance Inflaction Factor (VIF) lebih kecil dari 10, sehingga bisa disimpulkan data analisis bebas multikolinearitas dan bisa dilanjutkan pada analisis berikutnya.

c) Uji Heteroskedastisitas

Pengujian ini dilakukan dengan tujuan untuk mencari tahu apakah terdapat penyimpangan atau penyelewengan pendapat atau asumsi atas tidaksamanya residual dengan varian berdasarkan 
pengamatan yang telah dilakukan sesuai dengan model regresi yang ada. Dalam penggunaan model regresi ini, harus dipenuhi syarat tidak ditemukannya gejala heteroskedastisitas. Adapun metode yang bisa digunakan untuk mengujinya adalah dengan cara menguji Glesjer. Dalam uji ini dikerjakan dengan melakukan regresi antar variable yang independen dengan nilai yang absolut residualnya yakni ABS_RES. Jika nilai signifikansi antar variable independent dan absolut residu nya melebihi 0,5 maka permasalahan terkait heteroskedastisitas tidak akan muncul. Hasilnya dapat dilihat dalam table berikut.

Tabel 3

Uji Heteroskedastisitas

Coefficients $^{\mathrm{a}}$

\begin{tabular}{|c|c|c|c|c|c|c|c|c|}
\hline \multirow[b]{2}{*}{ Model } & \multicolumn{2}{|c|}{$\begin{array}{l}\text { Unstandardized } \\
\text { Coefficients } \\
\end{array}$} & \multirow{2}{*}{\begin{tabular}{|l}
$\begin{array}{l}\text { Standardized } \\
\text { Coefficients }\end{array}$ \\
Beta \\
\end{tabular}} & \multirow[b]{2}{*}{$\mathrm{t}$} & \multirow[b]{2}{*}{ Sig. } & \multicolumn{3}{|c|}{ Correlations } \\
\hline & $\mathrm{B}$ & Std. Error & & & & $\begin{array}{l}\text { Zero- } \\
\text { order }\end{array}$ & Partial & Part \\
\hline 1 (Constant) & 1.015 & .227 & & 4.469 & .000 & & & \\
\hline Kualitas Produk & .066 & .020 & .703 & 3.350 & .301 & -.088 & .333 & .317 \\
\hline $\begin{array}{l}\text { Gaya \& Desain } \\
\text { Produk }\end{array}$ & -.024 & .018 & -.195 & - & .200 & -.274 & -.135 & -122 \\
\hline Harga Produk & -.028 & .020 & -.249 & - & .167 & -.237 & -.145 & -132 \\
\hline Merek Produk & -.037 & .018 & -.344 & - & .244 & -.278 & -.210 & -193 \\
\hline $\begin{array}{l}\text { Pelayanan } \\
\text { Produk }\end{array}$ & -.023 & .022 & -.214 & $\begin{array}{l}- \\
1.039\end{array}$ & .302 & -.216 & -.109 & $\begin{array}{l}- \\
.098 \\
\end{array}$ \\
\hline
\end{tabular}

a. Dependent Variable: Abs_RES

Berdasarkan tabel diatas, terlihat bahwa nilai signifikansi antara variabel independen dengan absolut residualnya lebih besar dari 0,05 sehingga bisa disimpulkan data analisis tidak terjadi masalah heteroskedastisitas, jadi analisis selanjutnya menggunakan analisis regresi linier berganda bisa dilanjutkan.

\section{Analisis Regresi Linier Berganda dan Pengujian Hipotesis}

Untuk mengetahui apakah kelima variabel atribut produk yaitu: kualitas produk (X1), gaya dan desain produk (X2), harga produk (X3), merek produk (X4) dan pelayanan produk (X5) berpengaruh positif dan signifikan terhadap loyalitas pelanggan (Y) Gorontalo Post, maka analisisnya menggunakan model analisis regresi linear berganda dengan bantuan program statistik SPSS dan sesuai dengan konsep penelitian ini.

Penelitian ini telah memenuhi syarat untuk menggunakan pengujian regresi linear berganda, sehingga analisis selanjutnya dapat digunakan. Untuk mengetahui secara ringkas besarnya koefisien parsial, koefisien regresi dan signifikansi serta determinasi indeksnya, maka dapat dilihat dalam tabel 4 berikut ini: 
Tabel 4. Hasil Analisis Regresi Linier Berganda

Coefficients $^{\mathbf{a}}$

\begin{tabular}{|c|c|c|c|c|c|c|c|c|c|c|}
\hline \multirow[b]{2}{*}{ Model } & \multicolumn{2}{|c|}{$\begin{array}{l}\text { Unstandardized } \\
\text { Coefficients }\end{array}$} & \multirow{2}{*}{\begin{tabular}{|l}
$\begin{array}{l}\text { Standardized } \\
\text { Coefficients }\end{array}$ \\
Beta
\end{tabular}} & \multirow[b]{2}{*}{$\mathrm{t}$} & \multirow[b]{2}{*}{ Sig. } & \multicolumn{3}{|c|}{ Correlations } & \multicolumn{2}{|c|}{$\begin{array}{l}\text { Collinearity } \\
\text { Statistics }\end{array}$} \\
\hline & B & Std. Error & & & & $\begin{array}{l}\text { Zero- } \\
\text { order }\end{array}$ & Partial & Part & Tolerance & VIF \\
\hline 1 (Constant) & .754 & .291 & & 2.587 & .011 & & & & & \\
\hline $\begin{array}{l}\text { Kualitas } \\
\text { Produk }\end{array}$ & .693 & .025 & .626 & 6.994 & .000 & .994 & .687 & .418 & .204 & 4.908 \\
\hline $\begin{array}{l}\text { Gaya } \& \\
\text { Desain Produk }\end{array}$ & .402 & .024 & .402 & .858 & .039 & .715 & .409 & .101 & .395 & 2.532 \\
\hline Harga Produk & .620 & .026 & .502 & .787 & .043 & .818 & .608 & .201 & .281 & 3.556 \\
\hline Merek Produk & .532 & .023 & .403 & 1.352 & .018 & .795 & .514 & .302 & .315 & 3.173 \\
\hline $\begin{array}{l}\text { Pelayanan } \\
\text { Produk }\end{array}$ & .630 & .029 & .526 & 1.500 & .030 & .862 & .611 & .012 & .211 & 4.748 \\
\hline
\end{tabular}

a. Dependent Variable: Loyalitas

Berdasarkan tabel di atas, menunjukkan bahwa persamaan regresi berganda dari model penelitian ini adalah sebagai berikut: $\mathrm{Y}=0,754+0,626 \mathrm{X}_{1}+0,402 \mathrm{X}_{2}+0,502 \mathrm{X}_{3}+0,403 \mathrm{X}_{4}+0,526 \mathrm{X}_{5}$

Hasil persamaan regresi linier berganda yang diperoleh dapat diinterpretasikan sebagai berikut:

Nilai 0,754 merupakan nilai konstansta yang berarti jika semua variabel bebas tidak ada (Nilai 0), maka loyalitas pelanggan berada pada nilai tersebut. Nilai 0,626 (X1) berarti jika ada penambahan 1 nilai variabel kualitas produk akan meningkatkan loyalitas pelanggan sebesar 0,626 dengan asumsi variabel bebas yang lain dari model regresi adalah tetap. Nilai 0,402 (X2) berarti jika ada penambahan 1 nilai variabel gaya dan desain produk akan meningkatkan loyalitas sebesar 0,402 dengan asumsi variabel bebas yang lain dari model regresi adalah tetap.

Nilai 0,502 (X3) berarti jika ada penambahan 1 nilai variabel harga produk akan meningkatkan loyalitas pelanggan sebesar 0,502 dengan asumsi variabel bebas yang lain dari model regresi adalah tetap. Nilai 0,403 (X4) berarti jika ada penambahan 1 nilai variabel merek produk akan meningkatkan loyalitas pelanggan sebesar 0,403 dengan asumsi variabel bebas yang lain dari model regresi adalah tetap. Nilai 0,526 (X5) berarti jika ada penambahan 1 nilai variabel pelayanan produk akan meningkatkan loyalitas pelanggan sebesar 0,526 dengan asumsi variabel bebas yang lain dari model regresi adalah tetap.

Pengujian t dilakukan guna mencari tahu variable independen yang secara parsial memberi dampk signifikan terhadap variable dependen. Derajat signifikansi yang digunakan adalah 0,05. Jika nilai signifikan lebih kecil dari derajat kepercayaan maka menerima hipotesis alternatif, dimana satu variable independen secara partial memberi pengaruh terhadap variable dependen.

Berdasarkan tabel 4 menunjukkan bahwa secara parsial kualitas produk memiliki nilai $t=6,994$ dengan nilai signifikansi 0,000 ; gaya dan desain produk memiliki nilai $\mathrm{t}=0,858$ dengan nilai signifikansi 0,039; harga produk memiliki nilai $\mathrm{t}=0,787$ dengan nilai signifikansi 0,043 ; merek produk memiliki nilai $\mathrm{t}=1,352$ dengan nilai signifikansi 0,018 ; pelayanan produk memiliki nilai $\mathrm{t}=1,500$ dengan nilai signifikansi 0,030. Dari data ini bisa disimpulkan semua variabel memiliki nilai t positif 
dan tingkat signifikansi lebih kecil dari 0,05 yang berarti bahwa semua variabel independen berpengaruh positif dan signifikan terhadap variabel dependen.

Tabel 5

Uji Simultan

Model Summary

\begin{tabular}{|c|c|c|c|c|c|c|c|c|c|c|}
\hline \multirow[b]{2}{*}{ Model } & \multirow[b]{2}{*}{ R } & \multirow[b]{2}{*}{$\begin{array}{l}\mathrm{R} \\
\text { Square }\end{array}$} & \multirow[b]{2}{*}{$\begin{array}{l}\text { Adjusted } \\
\text { Square }\end{array}$} & \multirow[b]{2}{*}{$\begin{array}{l}\text { Std. Error of } \\
\text { the Estimate }\end{array}$} & \multicolumn{5}{|c|}{ Change Statistics } & \multirow[t]{2}{*}{$\begin{array}{l}\text { Durbin- } \\
\text { Watson }\end{array}$} \\
\hline & & & & & $\begin{array}{l}\mathrm{R} \text { Square } \\
\text { Change }\end{array}$ & $\begin{array}{l}\mathrm{F} \\
\text { Change }\end{array}$ & df & df2 & $\begin{array}{l}\text { Sig. F } \\
\text { Change }\end{array}$ & \\
\hline 1 & $.994^{\mathrm{a}}$ & .989 & .988 & .30996 & .989 & 1549.435 & 5 & 90 & .000 & 1.376 \\
\hline
\end{tabular}

a. Predictors: (Constant), Pelayanan Produk, Gaya \& Desain Produk, Merek Produk, Harga Produk, Kualitas Produk

b. Dependent Variable: Loyalitas

Berdasarkan hasil analisis statistik melalui Program SPSS, menunjukkan bahwa secara bersama-sama kelima variabel bebas, yaitu: kualitas produk (X1), gaya dan desain produk (X2), harga produk (X3), merek produk (X4) dan pelayanan produk (X5) memiliki pengaruh positif dan signifikan terhadap loyalitas pelanggan $(\mathrm{Y})$ yang dapat ditunjukkan melalui nilai Fhitung $=1549,435$ dan Probability (sig) $=0,000<\alpha=0,05$

Sedang kontribusi atau sumbangan pengaruh lima variabel bebas sangat besar dimana dapat ditunjukkan melalui nilai indeks determinasi $(\mathrm{R} 2)=0,989$ atau $98,90 \%$ variasi loyalitas dan terdapat 0,011 atau 1,1\% loyalitas pelanggan ditentukan oleh faktor lain yang belum termasuk dalam penelitian ini. Dengan demikian maka kelima variabel tersebut dapat dijadikan prediksi untuk meningkatkan loyalitas pelanggan Gorontalo Post.

\section{Pembahasan}

\section{Pengaruh parsial kualitas produk terhadap Loyalitas pelanggan}

Keberhasilan suatu perusahaan khususnya Gorontalo Post merupakan pencerminan bahwa keberhasilan dalam menjalankan aktivitasnya sangat ditentukan oleh penerapan atribut produk, termasuk salah satunya adalah kualitas produk yang diterapkan oleh Gorontalo Post dalam mempengaruhi loyalitas pelanggan. Menurut Tjiptono (2013 : 103) atribut produk adalah unsur-unsur produk yang dipandang penting oleh konsumen dan dijadikan dasar pengambilan keputusan pembelian.

Hasil analisis penelitian ini membuktikan bahwa kualitas produk berpengaruh positif dan signifikan terhadap loyalitas pelanggan yang dapat dibuktikan dengan besaran nilai koefisien pengaruh dan tingkat signifikansinya. Kualitas produk menunjukkan kemampuan suatu produk untuk melakukan fungsi-fungsinya. Kemampuan itu meliputi daya tahan, kehandalan, ketelitian uang dihasilkan, kemudahan dioperasikan dan diperbaiki, dan atribut lain yang berharga pada produk secara keseluruhan. Agar dapat bersaing di pasar secara berhasil produk harus memiliki mutu yang unggul dibandingkan dengan produk-produk pesaing yang setingkat. Hanya perusahaan yang mempunyai kualitas yang terbaik yang akan berhasil dalam memenangkan persaingan. Sebagian besar perusahaan menyadari akan pentingnya kulitas, maka mereka mengimplemantasikan program Manajemen kulitas total (TQM), yaitu usaha-usaha untuk meningkatkan kualitas produk dan proses secara konsisten di setiap tahap dalam kegiatan operasinya. 
Kaitan dengan penelitian terdahulu terlihat memiliki persamaan dan perbedaan. Penelitian dengan judul Pengaruh atribut produk dan Minat Konsumen Terhadap loyalitas Konsumen (Studi kasus Pada AJB Bumiputera 1912) di Surakarta oleh M.Noor Fauzan dan Trigunarsih (2015), dimana penelitian ini mendukung penelitian terdahulu yang membuktikan bahwa atribut produk berpengaruh positif dan signifikan terhadap loyalitas pelanggan.

\section{Gaya Dan Desain Produk Terhadap Loyalitas Pelanggan}

Loyalitas pelanggan Gorontalo Post merupakan pencerminan bahwa keberhasilan perusahaan dalam menjalankan aktivitasnya, dimana hal ini sangat ditentukan oleh atribut produk, termasuk salah satunya adalah gaya dan desain produk yang diterapkan oleh Gorontalo Post dalam mempengaruhi loyalitas pelanggan. Hal ini sesuai dengan teori yang dikemukakan oleh Simarora $(2011 ; 147)$ mendefinisikan atribut produk sebagai faktor-faktor yang dipertimbangkan saat membeli produk, seperti harga, kualitas, kelengkapan fungsi (fitur), desain, layanan purna jual, dan sebagainya. Suatu atribut produk merupakan suatu kesatuan dari bermacam-macam atribut yang membentuknya, dimana masing-masing atribut mempunyai kapasitas yang berbeda-beda dalam memberikan keputusan kepada pemakai produk tersebut.

Cara lain untuk menambahkan nilai pelanggan adalah melalui gaya dan desain produk yang khas. Konsep desain lebih luas dibandingkan gaya. Gaya mengedepankan tampilan luar dan sematamata menjelaskan penampilan produk tertentu. Sedangkan desain bukan sekedar tampilan luar semata, desain masuk ke jantung produk, desain yang baik dapat memberikan kontribusi dalam hal keg\$unaan produk dan juga penampilannya. Desain dapat menjadi alat persaingan yang sangat baik bagi armada pemasaran perusahaan.

Kaitan dengan penelitian terdahulu terlihat memiliki persamaan dan perbedaan. Penelitian terdahulu dengan judul Analisis Pengaruh Atribut Produk Terhadap Keputusan Konsumen Dalam Pembelian T - Shirt "In Tee - Shirt" Di Yogyakarta yang dilakukan oleh Ika Puji Lestari pada tahun (2014) memiliki kesamaan hasil bahwa gaya dan desain produk merupakan salah satu hal yang dipertimbangkan konsumen dalam melakukan pembelian.

\section{Harga produk Terhadap Loyalitas Karyawan}

Menurut Tjiptono (2013 : 103) dan Simamora (2011 :195), unsur-unsur yang penting dalam atribut produk diantaranya meliputi merek, kemasan, pemberian label (labeling), jaminan (garansi), harga, dan pelayanan. Hal ini menegaskan bahwa harga adalah atribut produk yang penting untuk diperhatikan perusahaan jika menginginkan pelanggannya loyal.

Hasil analisis penelitian ini membuktikan bahwa harga produk berpengaruh positif dan signifikan terhadap loyalitas pelanggan sehingga menunjukkan bahwa jika harga produk dapat disesuaikan, maka akan dapat meningkatkan loyalitas pelanggan. Harga merupakan uang yang dibayarkan atas suatu barang atau layanan yang diterima. Selain itu harga diartikan sebagai nilai yang dipertukarkan konsumen untuk suatu manfaat atas pengkonsumsian, penggunaan, atau kepemilikan barang atau jasa. Banyak faktor yang perlu dipertimbangkan dalam menetapkan harga yang tepat. Bagi pembeli harga memberikan dampak ekonomis dan psikologis. Dampak ekonomisnya berkaitan dengan daya beli, sebab harga merupakan biaya (cost) bagi pemebeli. Semakin tinggi harga, semakin sedikit produk yang bisa mereka beli begitu juga sebaliknya. Sedangkan dampak psikologisnya yaitu apabila harga suatu produk tinggi maka mencermingkan kualitas tinggi dan harga rendah mencermingkan kualitas rendah pula. 
Kaitan dengan penelitian terdahulu memiliki persamaan dan perbedaan. Penelitian terdahulu tersebut adalah Dimas Is Ariyanto ,(2015), Analisis kualitas produk, kualitas pelayanan saluran distribusi dalam meningkatkan kepuasan member amway di kota semarang, dimana penelitian ini mendukung penelitian terdahulu yang menemukan bahwa jika konsumen merasa puas dengan harga produk, maka merke akan loyal terhadap produk tersebut.

\section{Merek produk Terhadap Loyalitas Pelanggan}

Menurut Tjiptono (2013 : 103) dan Simamora (2011 :195), unsur-unsur yang penting dalam atribut produk diantaranya meliputi merek, kemasan, pemberian label (labeling), jaminan (garansi), harga, dan pelayanan.

Merek merupakan nama, istilah, tanda, simbol/lambang, warna, gerak atau kombinasi atributatribut produk lainnya yang diharapkan dapat memberikan identitas dan diferensiasi terhadap produk pesaing. Merek yang baik dapat menyampaikan jaminan tambahan berupa jaminan kualitas. Hasil analisis penelitian ini membuktikan bahwa merek produk yang dimiliki oleh Gorontalo Post berpengaruh positif dan signifikan terhadap loyalitas pelanggan sehingga menunjukkan bahwa jika merek produk dapat ditingkatkan, maka akan dapat meningkatkan loyalitas pelanggan.

Kaitan dengan penelitian terdahulu terlihat memiliki persamaan dan perbedaan. Penelitian terdahulu tersebut adalah Akbar Ibrahim (2015) Analisis Ekperiential Marketing Terhadap Loyalitas Pelanggan Pada Kedaton Spa di Semarang. Penelitian ini mendukung penelitian terdahulu dimana kedua penelitian menemukan bahwa jika pelanggan punya persepsi yang sesuai dengan keinginannya seperti persepsi pada merek maka mereka akan loyal terhadap produk tersebut

\section{Pelayanan produk terhadap Loyalitas Pelanggan}

Pelayanan merupakan setiap kegiatan atau mannfaat yang ditawarkan suatu pihak kepada pihak lain, yang pada dasarnya tidak berwujud dan tidak mengakibatkan kepelikan apa pun. Salah satu cara untuk menderensiasikan suatu perusahaan adalah memberikan pelayanan yang lebih berkualitas dibandingkan dengan pesaing secara konsisten. Pelayanan mempunyai sumbangan penting terhadap keberhasilan produk dalam bersaing di pasar. Hasil analisis penelitian ini membuktikan bahwa pelayanan produk yang diberikan Gorontalo Post berpengaruh positif dan signifikan terhadap loyalitas pelanggan sehingga menunjukkan bahwa jika pelayanan produk dapat ditingkatkan, maka akan dapat meningkatkan loyalitas pelanggan. Setiap produk mempunyai atribut yang berbeda-beda, sehingga konsumen dihadapkan pada berbagai atribut yang ditawarkan oleh perusahaan. Perusahaan mempunyai tugas untuk memperhatikan dan mengevaluasi atribut produk yang ditawarkan, apakah atribut dari produk tersebut sudah memenuhni kebutuhan dan keinginan konsumen atau belum. Suatu atribut produk merupakan suatu kesatuan dari bermacam-macam atribut yang membentuknya, dimana masing-masing atribut mempunyai kapasitas yang berbeda-beda dalam memberikan keputusan kepada pemakai produk tersebut. Keputusan dalam membeli suatu produk merupakan faktor internal yang sulit dilihat dan diukur, sehingga konsumen atau pemakai produk akan memandang suatu produk dari sudut pandang yang berbeda-beda.

Kaitan dengan penelitaan terdahulu terlihat memiliki persamaan dan perbedaan yaitu penelitian dengan judul Pengaruh atribut produk dan Minat Konsumen Terhadap loyalitas Konsumen (Studi kasus Pada AJB Bumiputera 1912) di Surakarta oleh M.Noor Fauzan dan Trigunarsih (2015), dimana loyalitas pelanggan dapat ditingkatkan jika perusahaan mampu meningkatkan pelayanan atas produk tersebut. 


\section{SIMPULAN}

1. Secara simultan atribut produk yang terdiri dari kualitas produk, gaya dan desain produk, harga produk, merek produk,pelayanan produk memberikan pengaruh positif dan signifikan terhadap loyalitas pelanggan Gorontalo Post

2. Secara parsial dari masing-masing variabel bebas yang diteliti yaitu kualitas produk, gaya dan desain produk, harga produk, merek produk,pelayanan produk memberikan pengaruh terhadap loyalitas pelanggan Gorontalo Post. Indikator yang dominan dalam pembentukan kualitas produk adalah indikator kelengkapan berita. Indikator yang dominan dalam membentuk gaya dan desain produk Gorontalo Post adalah indikator Gaya bahasa yang santun. Indikator yang memiliki kontribusi dominan dalam harga produk adalah indikator kesesuaian harga dengan kualitas. Indikator yang dominan dalam membentuk merek produk pada Gorontalo Post adalah indikator merek mudah dikenal. Indikator yang dominan dalam membentuk pelayanan produk Gorontalo Post adalah indikator Pengiriman Gorontalo Post selalu tepat waktu

3. Hasil penelitian menunjukkan bahwa variabel kualitas produk yang diterapkan Gorontalo Post yang paling dominan berpengaruh terhadap loyalitas pelanggan.

\section{Daftar Pustaka}

Alma B, 2012, Manajemen Pemasaran dan Pemasaran jasa, Edisi revisi, cetakan kelima. Alfabeta. Bandung Alma B. 2013, Manajemen Pemasaran dan Pemasaran Jasa. Alfabeta. Bandung.

Algifari, 2015. Statistika Induktif untuk Ekonomi dan Bisnis. UPP AMP YKPN. Jakarta.

Angipora, P.M. 2012, Dasar-Dasar Pemasaran, edisi revisi, cetakan kedua, Raja Grafindo Persada Jakarta.

Assauri, Sofyan, 2015, Manajemen Pemasaran Produksi dan operasi. Lembaga penerbit Fakultas Ekonomi UI. Jakarta.

Assauri, Sofjan, 2009, Manajemen Pemasaran Dasar, Konsep, Strategi. PT.Raja Grafindo Persada. Jakarta. Bahri, 2015. Strategi Pemasaran Produk dan Jasa. Penerbit Prenhanlindo, Jakarta.

Dharmmesta dan Irawan. 2000. Manajemen Pemasaran Modern. Edisi Kedua. Liberty. Yogyakarta.

Francis Butlle, 2015. Manajemen hubungan Pelanggan. Bayumedia Publhising. Malang.

Gousali .S. 2013. Pelayanan dalam Promosi produk . Bandung :Tarsito

Ghozali. I. 2015. Aplikasi Analisis Multivariate dengan Program SPSS. UNDIP. Semarang.

Griffin. 2012. Costumer loyalty. Edisi Pertama. PT.Gelora Aksara Pratama. Jakarta.

Heizer, Jaya dan Render Barry, 2015, Manajemen Operasi, edisi ketujuh. Salemba Empat. Jakarta.

Hermawan. 2015. Bosting Loyalty Marketing Performance. Mark Kertajaya Plus. Jakarta.

Jispher, 2015. Manajemen Strategis dan kebijakan perusahaan. Edisi ketiga, Erlangga, Jakarta

Kertajaya,H. 2015. Hermawan Kertajaya On Marketing. PT Gramedia. Jakarta.

Kertajaya H. 2014. Marketing in Venus. PT. Gramedia. Jakarta

Kertajaya H. 2014. Bosting Loyalti Marketing Performance. Mark Plus. Jakarta.

Kotler, P. dan Amstrong. 2013. Dasar-dasar Pemasaran, alih bahasa Alexander Sindoro dan Tim Mark Plus. Jilid 1. Edisi kesembilan. PT Indeks Gramedia. Jakarta.

Kotler, P. dan Kevin L, 2015, Manajemen pemasaran, jilid I diterjemahkan Benyamin Molan. PT. Indeks Gramedia. Jakarta.

Kotler, P. dan Kevin L, 2015, Manajemen pemasaran, jilid II, dialih bahasakan oleh Bunyamin Molan . PT. Indeks Gramedia. Jakarta.

Kotler, P. Marketing. Alih bahasa: Herujati Purwoko. UNDIP, Semarang, Erlangga. Jakarta.

Krisnawati. L. Dan U.Sumarwan. 2014, Perilaku Konsumen, cetakan II. Ghalian Indonesia. Bogor. Lovelock, Christopher and Wirtz. 2014. Service marketing. Fifth Edition. Prentice Hall Internasional.

M, M. A., Karundeng, D. R., \& Suyanto, M. A. (2021). Pengaruh Bauran Promosi , Harga , Display Produk dan Kualitas Layanan terhadap Keputusan Pembelian pada Apotek Anugerah Farma di Kota 
Gorontalo. MABSYA: Jurnal Manajemen Bisnis Syariah Vol. 3, No. 1, Januari-Juni 2021, 3(1), 77-90.

Mauren. M. 2014. Studi Mengenai Loyalitas Pelanggan pada Divisi Asuransi. Kumpulan. AJB Bumi Putera. Jurnal Sains Pemasaran Indonesia Volume III nomor III halaman 289 - 308.

Musanto. T. 2014. Faktor - Faktor Kepuasan Pelanggan dan Loyalitas Pelanggan Studi Kasus pada CV. Sarana Media Advertising. Surabaya. Jurnal Manajemen dan Kewirausahaan Volume VI nomor II Halaman 123 - 136.

Nachrowi, 2015. Variabel-Variabel Penelitian. Yogyakarta : Andi.

Riduwan, 2013, Dasar-dasar Statistika, Edisi ketiga. Alfabeta. Bandung.

Sanibar, 2014. Pemasaran dan Kepuasan Konsumen, Balai Pustaka, Jakarta.

Sasono, 2013. Pemasaran Produk dan Jasa. Kanisius, Yogyakarta

Simarora, B. 2014. Riset Pemasaran. Gramedia Pustaka Utama. Jakarta.

Slamet. A. 2000. Dampak Sikap Konsumen Terhadap Keberadaan Pasar Tradisional Perkotaan dan Pasar Swalayan Terhadap Pola Prilaku Pembelian. UNPAD. Bandung.

Sudjana, 2013. Pengantar statistik, , Bandung : Tarsito.

Sugiyono. 2014. Metode Penelitian Bisnis. CV. Alfabeta. Bandung.

Suhendra, 2013. Tingkat kepuasan Pelanggan jasa. Bandung : PT.Rosda Karya

Sulastomo, 2015. Manajemen Pemasaran. BPFEE. Yogyakarta.

Suryana, 2008, Kewirausahaan kiat dan proses menuju sukses, edisi ketiga, Jakarta, Salemba Empat.

Suyanto, M. A., \& Setiawan, S. R. (2019). Model Kepercayaan Mahasiswa. Gorontalo Management Research. https://doi.org/10.32662/gomares.v2i 2.767

Suyanto, M. A., Usu, I., \& Moodoeto, M. J. (2019). The Role of Service Quality on Building Student Satisfaction. American Journal of Economics. https://doi.org/10.5923/j.economics.20190901.03

Tjiptono .F. 2015. Pemasaran Jasa. Bayumedia Publishing. Malang.

Umar, Husein 2008, Metode penelitian Untuk Skipsi dan Tesis Bisnis, Yogyakarta : Liberty

Widiyanto. 2014. Analisis Faktor yang Mempengaruhi Loyalitas Konsumen studi kasus pada Susu Anlene dari PT. New Zeland Milk (Indonesia). Jurnal Ekonomi dan Manajemen volume XIII halaman 1 7. 